\title{
DISTRIBUTION OF ADULT EDUCATION PARTICIPANTS IN BORSOD-ABAÚJ-ZEMPLÉN COUNTY
}

\author{
Dávid Hajdú* \\ Szent István Egyetem Doctoral School of Management and Business Administration, Gödöllő, Hungary
}

\begin{abstract}
The present study presents adult education institutions and participants in adult education at the national level, highlighting the Borsod-AbaújZemplén County. It shows the decrease in the number of tasks and the change in the types of maintainers, the decreasing trend of the number of privately maintained institutions and the number of students. Thanks to public interventions, private-run institutions have completely shrunk in the last 7 years due to support for training. Private institutions receive little or no state support for the teaching of the professions listed in the National Training Register, which means that students can only study in private schools for a fee. This decision resulted in the dissolution of most privately maintained institutions, their merging into local Vocational Training Centres or church institutions. The main goal of the research was to get a realistic picture of the causes of institutional change.
\end{abstract}

Keywords: human resources, adult education, state intervention

\section{Introduction}

Under the institutions of the European Union, adult education includes institutionalized, regulated (i.e. formal) educational activities for adults, which are less often used for vocational training, most often for general education, usually to fill gaps in basic skills, and to obtain a qualification or vocational qualification. In addition to formal adult education, non-formal, course-type trainings related to the participant's self-realization, hobbies and interests, which expand their knowledge, fit into the field of adult education policy. What distinguishes adult education from adult education is that adult education is primarily aimed at developing professional skills (Cedefop, 2004).

For the first time in UNESCO and EU policy documents, the terms adult education or adult education policy have been used to interpret lifelong learning, but these terms have been replaced by the term adult learning, which covers all informal, formal and non-formal learning, whether vocational or non-formal - general learning activities carried out by adults to complement studies (Council, 2011).

According to the preamble of the Adult Education Act [1] (Fktv.), the aim of the Act is to enable persons living in Hungary to meet the challenges of economic, technological and cultural development (Cseszka, 2017). They can be successfully integrated into the world of work, be successful throughout their lives and improve their way of life through adult education. There is a need to increase the organization of professional, language and supported trainings (Koncz, 2017).

The main goals of adult education and training are:

$\square$ enabling adults who have not obtained them for some reason in their previous education to obtain the missing education and initial vocational qualification;

$\square$ improving the competitiveness of knowledge and the economy;

$\square$ introducing state-supported vocational training and competence development programmes for disadvantaged groups in the labour market, in particular to promote the employment of those with a low level of education;

$\square$ ensuring equal opportunities, social cohesion and catching up with disadvantaged groups, $\square$ developing language competences in line with economic and technological developments;

$\square$ encouraging vocational and general adult education (Zachár, 2006).

Adult education is used as a term for school-based education of adults (Farkas, 2017). According to this, adult education is a training where "students participate in education adapted to their occupation at work, family or otherwise, their existing knowledge and age" (Act CXC of 2011 on National Public Education). Public education at any school level can also take place as adult education, i.e. primary education is secondary education, which also includes school-based vocational training and higher education is an integral part of an interdependent education system. It is regulated by the Public Education Act, as this activity is basically carried out in a public education institution (European Commission, 2020).

The purpose of the above-mentioned laws was formulated as follows: the right to education should prevail throughout the individual's life. The task of the state is to create the legal framework of adult education and adult education, to operate its institutional system, and to ensure its financing, to help adults to keep their jobs, possibly get new ones and promote the development of adults' constructive lives (Simonics and Tóth, 2016).

Today, pupils can start a new school year only in adult education from the year "in which they reached the seventeenth year in the case of an eight-grade primary school and in the twenty-fifth year of a secondary school" (European Commission, 2020). In high school, students can study in adult education from the school year in which they reach the age of sixteen. In Hungary, compulsory schooling lasts until the end of the sixteenth school year (Vámosi, 2018).

The functions of adult education and adult training are multi-layered in Hungary:

$\square$ creating second chance training;

$\square$ promoting the acquisition of professional qualifications, further professional training and higher education;

$\square$ helping to acquire marketable professional knowledge during the period of unemployment;

$\square$ promoting social integration among disadvantaged, disabled or disabled people;

$\square$ meeting the intellectual needs of adults; 


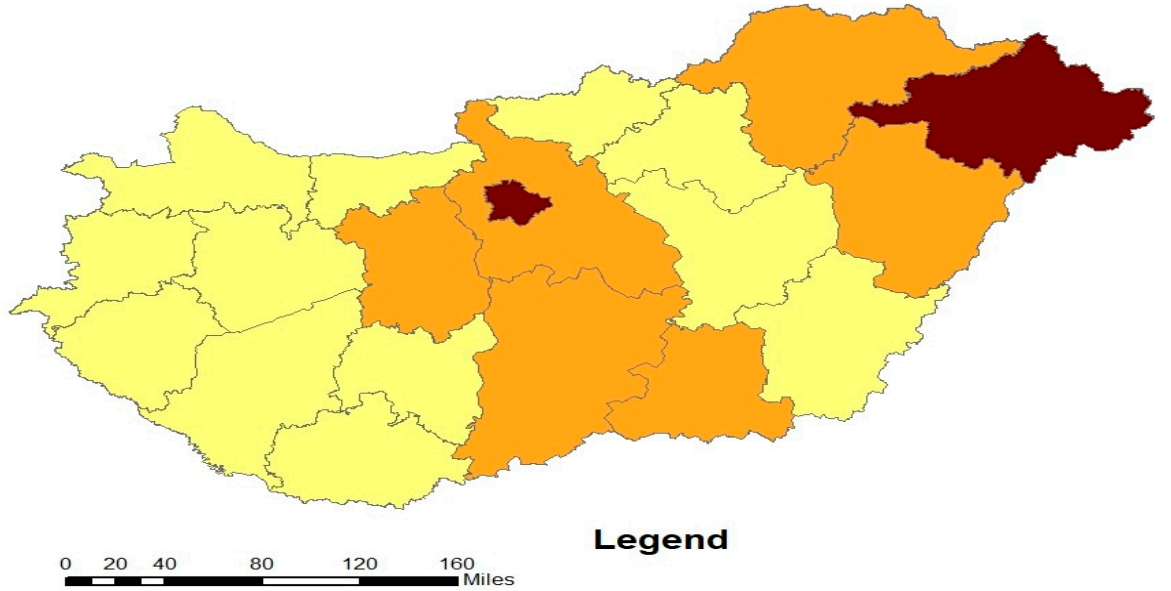

Participants in adult education

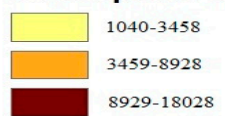

Figure 1 Territorial distribution of participants in adult education in Hungary (2019) Source: based on own creation (www.oktatas.hu/hivatali ugyek) $\square$ providing non-vocational knowledge or skills (European Commission, 2020).

\section{Material and methods}

The study presents the institutional and participant background of today's Hungarian adult education institutions. As a basis for the primary research, after studying the articles and textbooks of domestic and international journals available on the topic, the databases available on the statistical interface of the Public Education Information System for the counties of Hungary, mainly the Borsod-Abaúj-Zemplén County, were reviewed. The aim of the study is to present the marginalization of private schools in the field of adult education for the period 2013-2019. I processed and evaluated the collected databases with the help of the Microsoft Office 2013 program.

Adult education was attended by 90,000 people in Hungary last year (2019). The number of institutions dealing with adult education in the same year was 892. The spatial distribution of institutions shows a similar picture as the student distributions. Figure 1 also perfectly illustrates that the capital and the SzabolcsSzatmár-Bereg County had most of the students, but also most of the institutions. The number of students compared to the number of institutions, the average number of students per institution is 99 , with 4 counties and the capital (SzabolcsSzatmár-Bereg County, Pest County, Csongrád(sanád County and Hajdú-Bihar County) having above-average proportions in the country. The number of people completing primary school in adult education from the country stands out in the eastern counties of the country, including the
Borsod-Abaúj-Zemplén County and the SzabolcsSzatmár-Bereg County. It is clear that in the western part of the country, the services provided by adult education are not used by those living there, for a number of possible reasons. The main thing is that in Western Hungary the proportion of graduates is much higher, and the monthly net income is also higher, due to which they use the flexible, albeit paid education system of adult education, rather than free, but more compulsory adult education.

\section{Results and discussion}

In Hungary, the total of 611,820 people have participated in adult education in the last seven years. The largest headcount in 2016 was 100,092 people. Figure 2 also perfectly illustrates that year by year, as the number of job positions increases, the number of students increases in direct proportion to it. The declining number of students is also due to the smaller number of assignments. In the last two years, the number of stagnant of students. training sites has resulted in a stagnant number

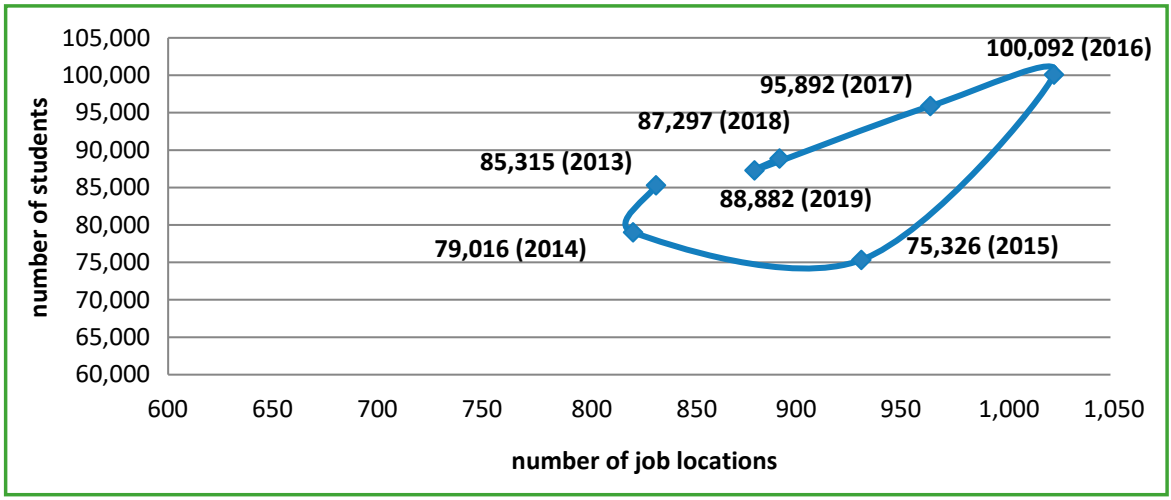

Figure 2 Beveridge curve Evolution of national student numbers by comparing the number of assignments (2013-2019)

Source: Based on own creation (www.oktatas.hu/hivatali_ ugyek)

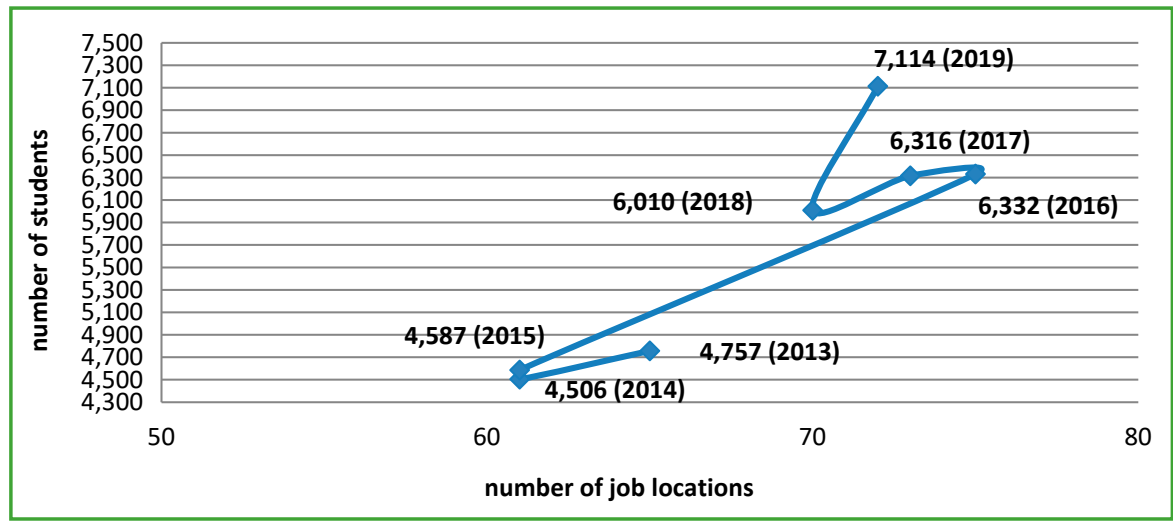

Figure 3 Beveridge curve Changes in student numbers Comparison of the number of assignments in the B-A-Z County (2013-2019)

Source: based on own creation (www.oktatas.hu/hivatali_ugyek) 


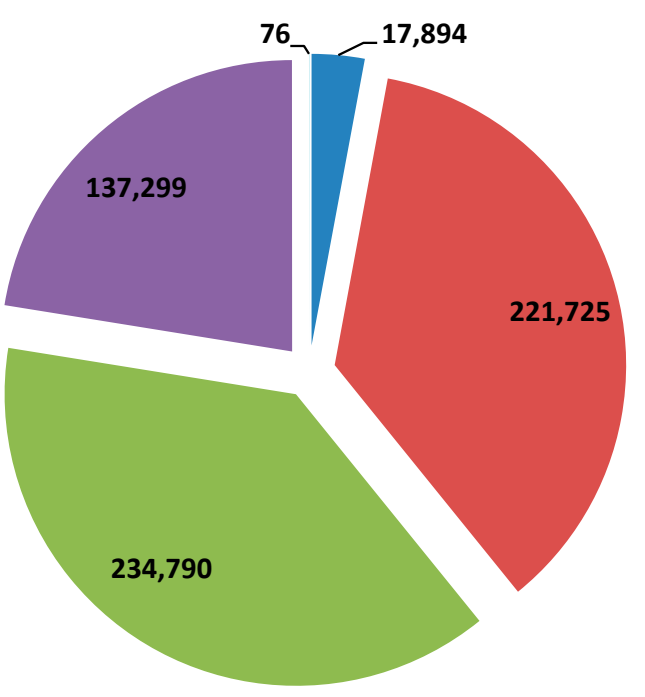

- primary schools

grammar school

vocational high school

vocational school

- special vocational school

Figure 4 Distribution of participants in adult education by type of task in Hungary (2013-2019) Source: based on own creation (www.oktatas.hu/hivatali_ugyek)

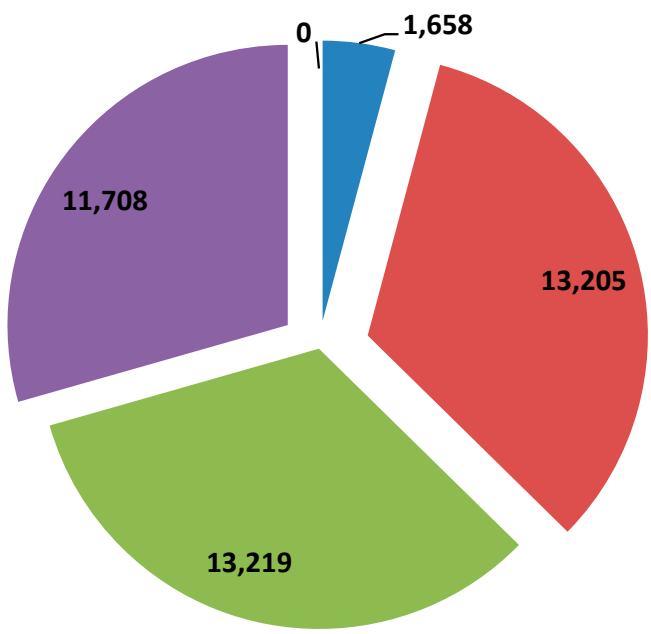

- primary schools

grammar school

vocational high school

vocational school

- special vocational school

Figure 5 Distribution of participants in adult education by type of task in the B-A-Z County (20132019)

Source: based on own creation (www.oktatas.hu/hivatali ugyek)

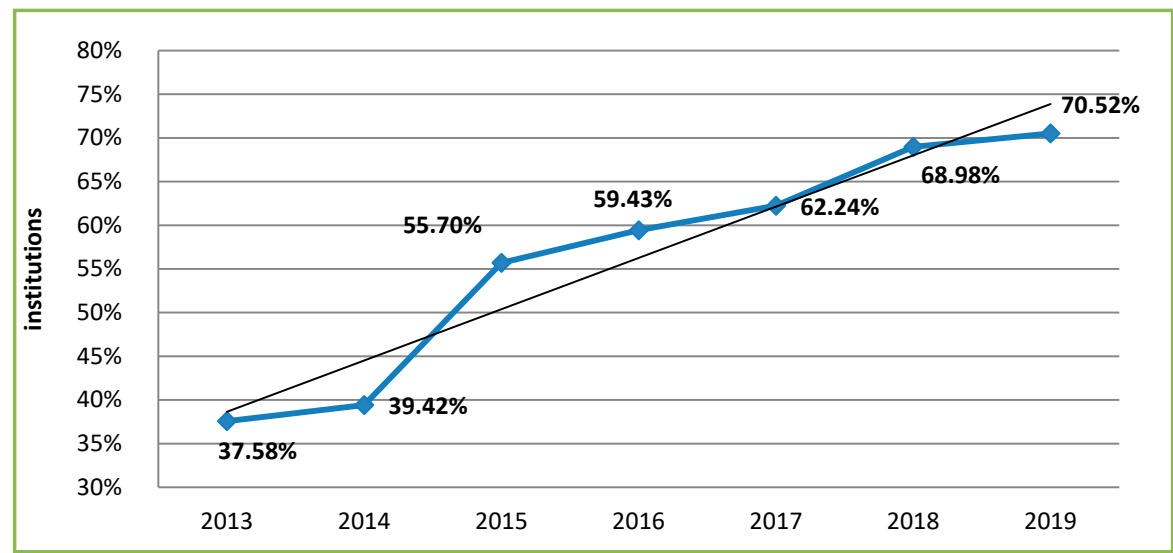

Figure 6 Development of the proportion of state and church-maintained institutions in Hungary (2013-2019)

Source: Based on own creation (www.oktatas.hu/hivatali ugyek)
The number of workplaces in the BorsodAbaúj-Zemplén County shows a continuous increase until 2016, but a slight decrease can be seen from 2016, which started to increase by 2019, and the number of students also moved accordingly. Compared to the national data, the statistical data of the County show a complete difference. The highest number of students in the County was in 2019, while the highest value in the country was in 2016, which has been showing a declining trend year by year since then. The largest number of training places in the County was in 2016 (75), compared to 2019 (72) there is hardly any decrease (Figure 3).

The longer duration of adult education is a problem for the more effective connection of training to the labour market. Nowadays, it is especially important to respond to current labour market needs. Students learn for 2-3 years in the course of vocational trainings included in the National Training Register, while in adult training this period is only 3-9 months. Of course, in adult education, practical training takes much longer, so a student who has completed the training is more likely to find such a job. However, only adult education is able to respond quickly to changes in the labor market. In adult education, students can study in most cases in a state-subsidized form, while in adult training, it is almost exclusively in a form of reimbursement, which prefers adult education, but statistics do not show this. Adults who want to learn usually take time into account when making a decision because it is the number one limiting factor for a full-time person raising their child.

The distribution of the last 7 years by type of task in Hungary is shown in Figure 4. The highest proportion (38.3\%) of students participated in the vocational high school type, followed by the grammar school type with $36.2 \%$. In my opinion, the following schols have the most significant role from the point of view of the labor market: vocational school, vocational high school and primary school - but for different target groups. These cover $63.7 \%$ of all training. Vocational high school and vocational school types are all vocational trainings, only the entry condition into the trainings distinguishes them from each other. Vocational school courses are based on completed $8^{\text {th }}$ primary school education, while vocational secondary school courses are based on a high school diploma. Primary school is important from the point of view of the labour market because it is essential for learning a new profession nowadays.

The Borsod-Abaúj-Zemplén County also shows a similar trend compared to the national trend. In the County, too, most participants 
were found in the vocational high school type, followed by the grammar school type. Compared to the national participation data, the County is outstanding in the primary school type, as it accounts for more than $9 \%$ of the country, in addition to which the vocational school type also stands out, which shows more than $8 \%$. Basically, those who want to finish primary school most often choose adult education rather than the form of adult education because of the shorter training time and flexibility.
Figure 6 also perfectly illustrates the extent to which state and church-maintained institutions have grown in the last 7 years, as in 2013 there were only 313 institutions of this type in Hungary, reaching 2019 by 2019 . The figure also beautifully shows the extent to which the private institution has been repressed.

The rise of state- and church-maintained institutions was the result of state support withdrawn from private schools, as a result of which they were not able to start professional

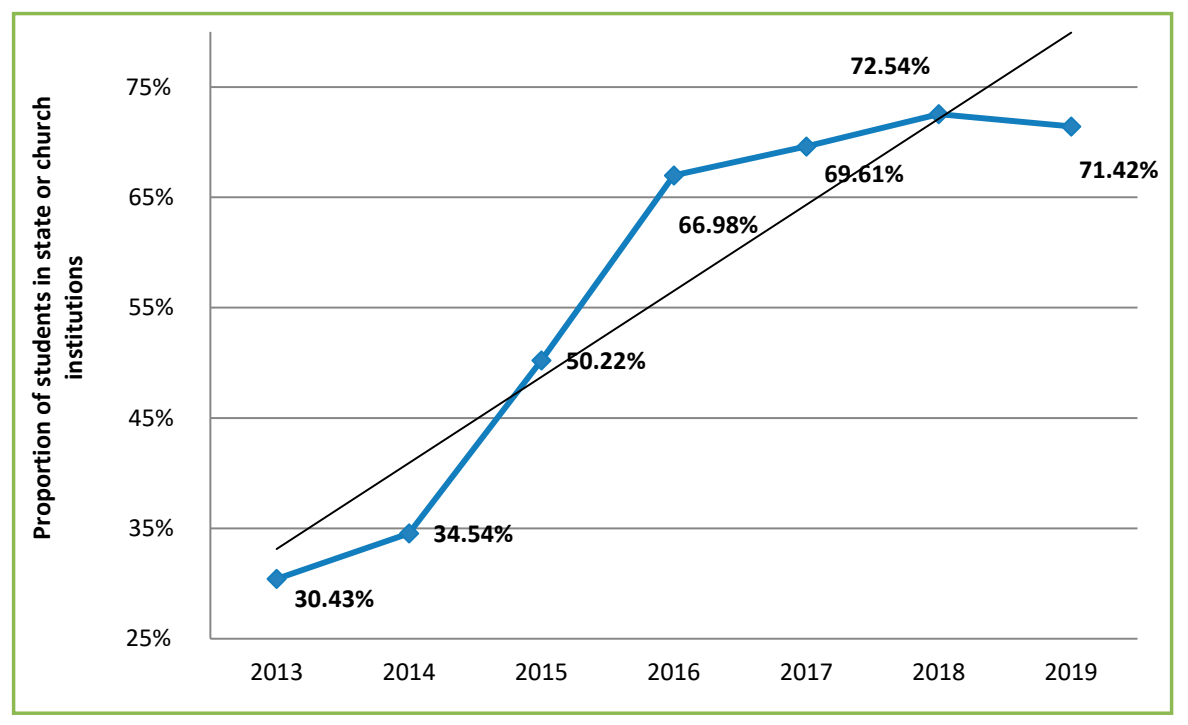

Figure 7 Development of the proportion of students in state and church-maintained institutions in Hungary (2013-2019)

Source: based on own creation (www.oktatas.hu/hivatali ugyek)

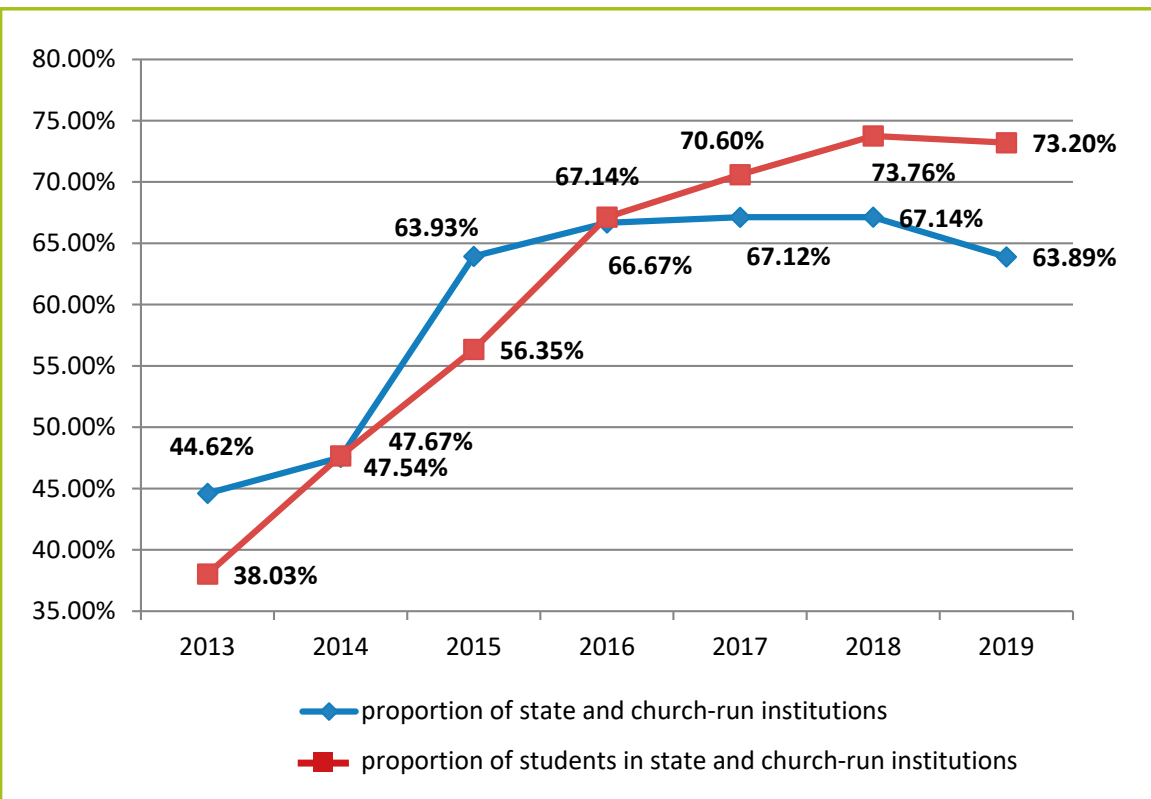

Figure 8 Development of the proportion of state- and church-maintained institutions and students in the B-A-Z County (2013-2019)

Source: based on own creation (www.oktatas.hu/hivatali ugyek) trainings listed in the National Training Register free of charge. A student who has chosen adult education as a form of training will, of course, choose free training for the same profession and will choose its institution, resulting in an increase in the number of students in state or church-run institutions.

The student proportions of state- and church-maintained institutions also show a similar picture to the development of institutions. The increased participation rate at these reserved institutions is due to state funding and support (Figure 7). Today, in a private school, students can study almost exclusively in a feebased form. This problem is not a problem in Budapest and Western Hungary at that time, as a solvent demand is available, but in the poorer counties it showed a huge decline in non-state and church-run institutions. As a result, many institutions have been unable to survive in the training market. Most of these institutions were merged into local Vocational Training Centres, and church institutions became the least chosen to close the school.

Figure 8 also illustrates well that the proportions of the Borsod-Abaúj-Zemplén County are almost entirely the same as the national situation. There are two most striking differences, the proportion of church-run institutions in the county was $7 \%$ higher at the beginning of the study period than nationally, which also attracted $8 \%$ more students of the national rate.

While in the country there is only a $1-2 \%$ difference between the participation and the institutional ratio, in contrast to the County, ta 10\% difference developed by 2019. Despite the fact that there are fewer state and church-run adult education institutions in the County, there is still a greater participation.

In the Borsod-Abaúi-Zemplén County, almost $50 \%$ of training institutions are located in the county seat Miskolc, thus further affecting the backwardness of the countryside. A person living in the countryside cannot choose from a range of training that meets his or her own interests and needs compared to a resident of Miskolc, but it can also be said that much training can only be found in Budapest, the capital. There may be a number of reasons for this, but the main problems are the location of practical training and the lack of interest in which professions attract few people, they are almost exclusively concentrated in the capital. 


\section{Conclusions}

Adult education institutions in Hungary are largely concentrated in the capital and County capitals, as a result of which the educational attainment of those living in rural areas is minimal, thus increasing both the economic and social backwardness of rural areas.

The decrease in the number of training institutions resulted in a decrease in the number of participants in trainings, which is due to the role of the state, as participants can study only in state or church-run institutions without reimbursement of training costs. This fact did not cause such a decrease in the number of participants in Budapest or in the more successful Western Hungary as in the Eastern parts of the country, where there is no solvent demand for trainings. Students who want to study in a fee-paying form mostly choose adult education due to lack of time, which is more flexible and in which the same profession can be acquired in a shorter time than in adult education.

Most people attend vocational trainings, both in the country and in the County. Of course, there is a reason for this in the labour market, because with a new profession it is easier for a participant to find or keep a job.

\section{References}

CEDEFOP. 2004. Terminology of European Education and Training Policy. Luxembourg: Publications Office of the European Union, 2004.

COUNCIL. 2011. Council Resolution on a renewed European agenda for adult learning (2011/C 372/01).
CSESZKA, É. 2017. A felnőttoktatás hatékonysága, különös tekintettel a hátrányos helyzetú rétegek képzésének nehézségeire és lehetőségeire In: Katona, K. - Kőrösi, I. (szerk.) A humán tőke szerepe a gazdaságban. Budapest : Pázmány Press, 2017, pp. 55-75.

EUROPEAN COMMISSION. 2020. Magyarország: Felnőttoktatás és felnőttképzés, pp.1-4.

FARKAS, É. 2017. A tanulási eredmény alapú képzésfejlesztés hatása a felnőttkori tanulás minőségére. In Opus et educatio/Munka és nevelés, vol. 4, 2017, no. 4 pp. 431-448.

KONCZ, G. 2017. Demográfiai folyamatok és humán erőforrások Észak-Magyarország vidéki térségeiben In: Koncz, G. (szerk.) Mérföldkövek a gyöngyösi agrárkutatásban Gyöngyös. Magyarország: Károly Róbert Kft., 2017, pp. 75-81.

SIMONICS, I. - TÓTH, P. (Sz.) 2016. Felnőttek szakképzése. Budapest : Typotop Kft, 2016, $103 \mathrm{p}$.

VÁMOSI, T. 2018. Átmenet a szakképzési rendszerből a munka világába Berlin. Németország: GlobeEdit, 2018, 80 p.

ZACHÁR, L. 2006. A felnőttképzés korszerú elvei és modelljei In: Koltai, D. - Lada, L. (szerk.) Az andragógia korszerű eszközeiről és módszereiről. Tanulmánykötet Budapest, Magyarország : Nemzeti Felnőttképzési Intézet, 2006, pp. 73-84.

\section{Contact address}

Dávid Hajdú, Szent István Egyetem Doctoral School of Management and Business Administration, Páter Károly utca1, 2100 Gödöllö, Hungary, e-mail: hajdu.david91@gmail.com 